\title{
CLINICAL CASE OF RARE ADRENAL TUMOR - SCHWANNOMA
}

Volkova N.I. ${ }^{1}$, Kit O.I. ${ }^{2}$, Porksheyan M.I. ${ }^{1}$, Dimitriadi S.N. ${ }^{2}$, Kanaeva S.A. ${ }^{1}$

${ }^{1}$ Rostov State Medical University, Rostov-on-Don

Rostov-on-Don, Russian Federation, dim3.rostgmu@gmail.com

${ }^{2}$ Rostov Scientific and Research Institute of Oncology, Rostov on Don, Russian Federation

\section{Background}

Schwannoma (Sch) is a rare peripheral nerve sheath tumor comprised entirely of neoplastic Schwann cells.

Adrenal Sch are extremely rare. Most adrenal Sch are incidental, and patients with Sch may not have any complaints.

\section{Clinical case}

Step 1. Urologist

Woman, 58 y.o., Complaint: painless macrohematuria
MRI was performed: giant mass $(14 \times 13 \times 11 \mathrm{~cm})$ with cystic degeneration and calcification, which was located in retroperitoneum

\section{Step 2. Endocrinologist}

\begin{tabular}{|c|c|c|}
\hline \multicolumn{3}{|c|}{$\begin{array}{l}\text { Hormonal examination } \\
\text { according to current protocols }\end{array}$} \\
\hline $\begin{array}{l}\text { plasma cortisol } \\
\text { after } 1-\mathrm{mg} \text { DST }\end{array}$ & $48 \mathrm{nmol} / \mathrm{l}$ & < $50 \mathrm{nmol} / \mathrm{l}$ \\
\hline $\begin{array}{l}\text { urinary } \\
\text { fractionated } \\
\text { metanephrines (M) }\end{array}$ & $\begin{array}{l}59 \mathrm{mcg} / 24- \\
\text { hour }\end{array}$ & $\begin{array}{l}\text { ( } 320 \mathrm{mcg} / 24- \\
\text { hour }\end{array}$ \\
\hline $\begin{array}{l}\text { urinary } \\
\text { fractionated } \\
\text { normetanephrines } \\
\text { (NM) }\end{array}$ & $\begin{array}{l}144 \\
\mathrm{mcg} / 24- \\
\text { hour }\end{array}$ & $\begin{array}{l}\text { ( } 390 \mathrm{mcg} / 24- \\
\text { hour }\end{array}$ \\
\hline
\end{tabular}

Right laparotomic adrenalectomy was performed without any intraoperative and postoperative complications.

\section{Step 4. Results}

Immunohistochemical assay showed that tumor cells were positive for S-100 protein and vimentin, which was consistent with schwannoma.

Genetic testing didn't revealed any associated mutations of schwannomatosis or neurofibromatosis type 2.

\section{Conclusions}

1. Because of rarity of adrenal Sch, it is of great importance to describe any case in order to understand true prevalence and natural history of the disease.
2. Sch as may be discovered incidental, as may be non-specific symptomatic.

3. Preoperative diagnosis of Sch is impossible in most cases, that's why strict following to diagnostic protocols is demanded in order to exclude all other causes of incidentalomas firstly.

Reference. *Hadfield KD et al. Molecular characterisation of SMARCB1 and NF2 in familial and sporadic schwannomatosis. J Med Genet. $2008 ; 45(6): 332$ 